\title{
Populist Political, Discursive and Ideological Definitions
}

\author{
Nancy del Rocio Flores Hinojosa \\ Administrative Sciences Department, Central University of Ecuador, Quito, Ecuador \\ Email:nrflores@uce.edu.ec
}

How to cite this paper: del Rocio Flores Hinojosa, N. (2021). Populist Political, Discursive and Ideological Definitions. Open Journal of Social Sciences, 9, 387-400. https://doi.org/10.4236/jss.2021.99027

Received: August 18, 2021

Accepted: September 13, 2021

Published: September 16, 2021

Copyright $\odot 2021$ by author(s) and Scientific Research Publishing Inc. This work is licensed under the Creative Commons Attribution International License (CC BY 4.0).

http://creativecommons.org/licenses/by/4.0/ (c) (i) Open Access

\begin{abstract}
This scientific contribution questions the economic, discursive and ideological definitions of populism and defends and develops a political-strategic conceptualization. The method used in this contribution is a bibliographic review under the search criteria "populist political currents" in the Web of Science database. In this way, 52 documents are detected. This academic material was reduced to 43 documents which were related and referenced in this manuscript. In addition, this research considers and refers to the material delivered in the Political Systems subject of the Doctorate in Public Administration program, of the National University of the Littoral, Faculty of Economic Sciences. The resulting definition emphasizes personalistic leadership that is based on the direct, unmediated, and institutionalized support of large masses of mostly unorganized followers. The contribution of this manuscript, resolved in: A theorization of populism. Analysis of the current discursive field of populism. Declaration of the common practices of populist leaders. A vision of the decline of notions of economic populism. Study of the incongruities between style and form, rhetoric and reality, of the populist currents. And last but not least, an analysis of the persistent confusion about populism.
\end{abstract}

\section{Keywords}

Political Sciences, Political Currents, Political Theory

\section{Introduction}

According to the Royal Spanish Academy and the Association of Academies of the Spanish Language, they agree that the definition of populism is: the political tendency that seeks to attract the popular classes. Populism and party politics are often studied separately, but neither can be understood in isolation from the other. Any explanation for the rise of populism must inevitably address the shortcom- 
ings of the party-based modes of political representation for which populism claims to offer a corrective. Indeed, populism thrives where the main parties are in crisis, or at least when they exclude or ignore the main currents of opinion in the political structure. The study of populism, therefore, must be situated in the broader domain of political representation and is necessarily intertwined with studies of economics, ideology, and party politics.

In the context of the aforementioned, it is sustained that: Populism is also defined as a political strategy through which a personalist leader seeks or exercises government power based on the direct, non-mediated and non-institutionalized support of a large number of followers, mostly unorganized (Weyland, 2001: p. 14). This concept highlights the crucial role of personalist leadership that sustains itself politically through the mobilization of numbers, that is, broad mass support. Given the personalistic nature of the government and the heterogeneity of the population, their connection lacks institutionalization and is based on the impression of direct contact. As these components come together, populism forms a coherent political strategy that has often served to win and maintain political power (de Vreese, Esser, Aalberg, Reinemann, \& Stanyer, 2018).

The central axis of the concept refers to the almost direct and immediate relationship between the prominent leader and the mass followers: populism mobilizes the "people", but this vast group is so diverse and heterogeneous that, instead of representing the multitude of specific interests in one In a pluralistic way, populism seeks to promote the general "will of the people", embodied in the leader (Falkenbach, Bekker, \& Greer, 2020). Thus, populism does not conceive of representation as a process, but assured through identity, that is, the identification of the leader with the people, and vice versa. Since the leader personifies the will of the people, the relationship between the leader and the followers is seen as a personal connection. This deep association gives populism the intensity that provides many followers with a sense of belonging, which liberal and pluralist democracy lacks, with its reliance on "cold" procedural mechanisms (Fiske, 2019).

Charisma is not a defining component of populism (Pierson, 2017) but the widespread belief in the amazing, extraordinary, and "supernatural" capabilities of a leader is a primary way in which the connection (Bavili, 2017) between leader and followers can acquire special intensity that gives rise to and sustains populism. If people are convinced of the saving and redemptive qualities of a leader (Zúquete, 2007: p. 23), they will offer a deep commitment. The resulting link is direct and avoids any organizational intermediation; to the extent that there are subordinates in the populist movement, they have only borrowed authority as the leader's anointed "disciples". Charisma is therefore a great example of the "glue" that can hold together a leader's direct relationship with a mass of followers and that can give this connection a deeply personal character (Hirschl \& Spisak, 2020).

The strategic definition of populism through the combination of personalistic leadership and reliance on numbers as the main power capacity also suggests what 
the main alternatives to populism are. When the personalist leader is stronger, it arises, patrimonialism, economic power, or caudillismo, military coercion. On the other hand, a system of government that is based on a large number of people but is headed by an informal grouping is held together by clientelism; while the predominance of the formal organization gives rise to the party government (Makarychev \& Sazonov, 2019). The poles opposed to populism in this two-dimensional conceptualization are the government of the military as an institution, that is, a formal organization that depends on armed coercion and corporatism, formal organizations that depend on economic power (McGarry, 2017: p. 19). The described scenario justifies and establishes the pertinacity of this research that aims to present an analysis of the leadership, the economic, discursive and ideological definitions of the populist political currents. The main results of this research are exposed in the following points: 1) Theorization of populism, an attempt; 2) Current discursive scope of populism; 3) Common practices of populist leaders; 4) The decline of notions of economic populism; 5) Incongruences between style and form, rhetoric and reality, of the populist currents; 6) Confusion and populism.

\section{Materials and Methods}

As material in this research, the powerful academic directory of science socialization Web of Science is used. Another known as Web of Knowledge is a website that provides subscription access to multiple databases that provide comprehensive citation information for many different academic disciplines. It was originally produced by the Institute for Scientific Information (ISI) and is currently maintained by Clarivate Analytics (Bravo, González, \& González, 2018).

This academic directory establishes academic dissemination priorities based on the citation index. A citation index is based on the fact that scientific citations serve as links between similar research items and lead to related or coinciding scientific literature, such as journal articles, conference proceedings, abstracts, etc. In addition, the literature that shows the greatest impact in a particular field, or more than one discipline, can be easily located through a citation index. For example, the influence of an article can be determined by linking to all articles that have cited it. In this way, current trends, patterns and emerging research fields can be evaluated (Bravo Hidalgo \& León González, 2018).

Using this criterion of weighting by citation and using the French search criterion: "populist political currents". 52 article-type scientific contributions were detected, contained in the last 30 years. This academic material was reduced to 43 documents which were related and referenced in this manuscript. In addition, this research considers and refers to the material delivered in the Political Systems subject of the Doctorate in Public Administration program, of the National University of the Littoral, Faculty of Economic Sciences.

\section{Results and Discussion}

It is undeniable that a manual of populism is a daring project, for that great so- 
cial mass less educated. This reality is demonstrated in the behavior of European nations in the first half of the 20th century, for example Germany and Russia, and currently in South American regions such as Venezuela and Argentina. By nature, a professional manual wants to condense and convey "the state of the art" in an area of study: What has been established by previous studies and what can serve as a conceptual and theoretical basis for future research and thoughts? The very term "state of the art" implies a certain degree of consolidation. But inherently populism is a fleeting concept that various scholars have compared to a chameleon (Taggart \& Parkin, 2000), constantly changing "colors" and threatening to escape analytical reach. As soon as academics trust that they have surrounded him with their defining traps, he resurfaces in a different way in another corner of the impenetrable jungle of politics (Ofosu-Anim \& Back, 2021). It is not surprising that the proliferation of "populisms with adjectives" or hyphens has continued during the last decade. After the researcher (Roberts, 1995) called it "neoliberal (neo) populism" that posited "unexpected affinities" (Weyland, 1996) between apparent opposites, proposals of surprising and provocative combinations have multiplied, with notions such as "ethno-populism" (Madrid, 2008) or “techno-populism” (De la Torre, 2013).

\subsection{Current Discursive Scope of Populism}

As the study of populism has seen a hundred flowers germinate, some old bulbs have also made new shoots sprout and have returned the faded colors. In particular, discursive and ideology-centered concepts of populism have made a significant comeback in recent years, due to methodological innovations and contemporary changes. Traditionally, discursive and ideological notions suffered from the difficulty of evaluation and measurement: given the vagueness of politicians' rhetoric, how can populist discourse be defined and delimited? But Kirk Hawkins' interesting reliance on holistic scoring techniques and his broad project to score the level of populism in the speeches of many leaders have given scholars confidence that measurement problems can be overcome. Hawkins's achievement has once again legitimized the discursive approach (Hawkins, 2009).

Furthermore, the recent wave of left-wing populists in Latin America enunciates a more attractive progressive discourse than that of the neoliberal populists of the 1990s with their appeals to conservative virtues such as order and discipline and their anti-intellectual tendencies. In fact, this group of Bolivarian leaders' attributes much more importance to discourse than their right-wing counterparts. While Alberto Fujimori's motto was "First you act; then you talk", Hugo Chávez kept talking, talking, talking, and then sometimes he acted. As the endless hours of "Aló Presidente" show, the speech played a central role in Chávez's populism.

This crucial role of discourse has shaped the image of left-wing populists. Unlike Carlos Menem, Fernando Collor, and Alberto Fujimori, despised by sophisticated public opinion, Chávez, Evo Morales, and, at first, Rafael Correa garnered considerable support from segments of the world's intelligentsia. While 
Menem had to settle for blonde supermodels and sassy racing drivers, Chávez was endorsed by MIT professor Noam Chomsky and actor Sean Penn; the support of the cosmopolitan intelligentsia, more than the rude superficiality, impelled the Bolivarian leader. None of these celebrities lived in the countries whose presidents they praised; thus, they were saved from the explosion of crime, stubborn inflation and frequent shortages in Venezuela. Instead, their admiration was drawn primarily by progressive discourse, left-wing ideology, and the noble pronouncements of these populist leaders (Bavili, 2017).

The progressive brilliance and central role of Bolivarian discourse has also helped inspire scholars to take the discursive and ideological dimension of populism more seriously and emphasize this dimension as a defining characteristic (Gibson \& Falleti, 2007). In fact, the most prominent proponent of a discursive approach in Latin America, Ernesto Laclau, has applied his theory to the current crop of left-wing populists, for example (Laclau, 2009) and the work of Svampa (2013) can also be considered and thus he has tried to suggest the continued usefulness of his approach presented systematically in (Laclau, 2005). These discursive and theoretical trends have also found resonance in southern Europe, especially with the appearance of PODEMOS in Spain and, less directly, SYRIZA in Greece (Hawkins \& da Silva, 2016).

In summary, methodological advances in academia and high-profile developments in politics have given new impetus to discursive and ideology-centered concepts of populism in the academic community (Orozco, 2016). This has led to the resurrection of an old approach that was being marginalized by the growing adoption of political-strategic definitions emerging from the analysis of neoliberal populism, more systematically codified in (Weyland, 2001). While neologisms such as ethnopopulism are shown in the work (Madrid, 2008), rentier populism at work (Mazzuca, 2013) and technopopulism in the document (De la Torre, 2013) capture only localized varieties (the central Andes, Latin America "radical" left, and Ecuador, respectively), the discursive and ideology-centered approach constitutes a fundamental alternative to political-strategic definitions in general (Rooduijn, 2014: p. 576).

\subsection{Common Practices of Populist Leaders}

Populist leaders always try to amalgamate the three powers, the executive, the congress and the judiciary. In this way they concentrate all power in themselves (Colomer, 1999). Populist programs focus on satisfying certain social problems and publicizing this fact, so that the populist leader becomes a healer of the nation. In this way, these populist parties in power increase public spending, multiply state employment, increase donations, subsidies and food royalties.

And in order to finance all these gifts, which try to talk to the nation that they are free, which is not true at all, since all production, resources or services have costs in the financial and economic structure of a nation; the parties or populist currents have to increase taxes, increase public debt, increase inflation, which ends up bleeding the now from the working class. This means that the state's 
spending is increasing and the social services and responsibilities of the state towards the citizens are increasingly poorer.

\subsection{Decline of Notions of Economic Populism}

Before contrasting the discursive and ideology-centered notions with the politico-strategic concepts of populism, it makes sense to highlight the fading of a third approach that burst onto the academic scene in the late 1980s and early 1990s, namely the notion of economic populism. Impressed by the dramatic boom-and-bust cycles in José Sarney's Brazil and Alan García’s Peru, well-known economists (Sachs, 1989) and (Dornbusch \& Edwards, 1991) identified populism with willful overspending and similar spasms of politically driven economic irresponsibility. From this point of view, a wide variety of political leaders sought to boost their massive support by distributing a plethora of economic benefits. But this short-term maximization of popularity flagrantly ruled out economic balances. This myopia soon caused a spiraling economic crisis that quickly evaporated the support of the presidents and resulted in an economic and political collapse, bringing great suffering and worsening poverty for the masses.

Inspired by these dramatic events, the notion of economic populism attracted much academic attention (Mair \& Katz, 1997). But from the beginning, the great diversity of politicians who were tagged with this tag raised questions about its conceptual validity and analytical utility, especially for political science. The classical populist Juan Perón, the neo-populist Alan García, the Marxist socialist Salvador Allende and the conservative José Sarney-the cases examined by (Sachs, 1989)-were very different political animals; Can a concept that encompasses them all be useful?

Furthermore, rapid social evolution seemed to refute the association of populism with economic irresponsibility postulated by Sachs (1989) and Dornbusch \& Edwards (1991). Precisely when these authors published their claims, a new wave of populist politicians embarked on an orthodox adjustment and profound market reform. Carlos Menem, Fernando Collor, and Alberto Fujimori consistently applied populist strategies and tactics to advance their political leadership, but at the same time enacted comprehensive neoliberal reform programs in close consultation with the global sheriffs of economic orthodoxy, the International Monetary Fund and the World Bank.

These "unexpected affinities" of populism and economic liberalism (Weyland, 1996) showed that populism cannot be defined through disregard for neoliberal principles such as budget discipline and monetary balance. Even the reappearance of radical left-wing populism in contemporary Latin America has not restored the usefulness of economic notions of populism. Among the new leaders, Evo Morales has maintained budget discipline and avoided irresponsibility" (Edwards, 2010: p. 171) and (Madrid, Hunter, \& Weyland, 2010), while Rafael Correa has refrained from challenging the crucial limitations imposed by their neoliberal predecessors and cemented by dollarization. And while Hugo Chávez clearly engaged in overspending, amassed massive debt, suffocated the national 
economy, and made Venezuela hyper-dependent on imports, the continued influx of exorbitant oil rents allowed him to postpone the long-predicted doomsday weather. Thus, the collapse predicted by economists' theories of the populist cycle was long averted. The consequent lack of a "paradigmatic" case of dramatic failure has confined economic notions to the margins of the contemporary debate on populism (Edwards, 2010).

\subsection{Incongruences between Style and Form, Rhetoric and Reality, of the Populist Currents}

Recent ideational definitions also misunderstand the meaning of populism. Populism often shows a significant disjunction between form and substance, style and strategy, rhetoric and reality. Ideational notions overlook these chasms by relying on populism's self-description as a movement of the "people" confronting corrupt elites. This discourse suggests that the popular sovereign can and should have political agency: "the people" finally take the destiny of the country into their own hands and shed the dominance of selfish elites. Therefore, populism seeks to empower the popular sovereign.

But these self-representations overlook a crucial fact: because "people," a very large aggregate, are amorphous, heterogeneous, and largely disorganized, they cannot exercise effective agency; the dilemmas of collective action exclude it. Instead, it is the very essence of populism that rhetorically empowered people necessarily follow a leader who claims to act on his behalf (Gibert, Gunther, \& Linz, 2007). The typical populist movement is to identify the "people" with this leader, and then to give the leader the power that emanates from the people. This populist turn reverses the direction of political influence. While, by omitting the crucial role of leadership, the speech implicitly depicts populism as a bottom-up mass movement, it actually relies on a top-down strategy through which a leader gathers plebiscitary support for the goals. That she herself determines. By ignoring this fundamental reversal and not even including personalistic leadership in the definition, discursive and ideology-centered notions fail to grasp the central meaning of populism. They focus on the surface and lose the very axis around which populism revolves (Makarychev \& Sazonov, 2019).

The neglect of personalistic and plebiscitary leadership is doubly surprising. First, recent ideational approaches are often derived from the analysis of rightwing movements in Europe (Mudde, 2007), where personalist leadership predominates and the empowerment of the "people" is conspicuous by its absence (Pelinka, 2013); case studies in authors' book (Albertazzi \& McDonnell, 2007). Second, Hawkins' discursive approach punctuates speeches made by top leaders, not official pronouncements of the movement in general. Therefore, the data collection actually focuses on the top politicians, but the conceptual discussion does not highlight the decisive role of these politicians (Hawkins, 2010).

By neglecting the automatic transfer of sovereignty "of the people" to a personalistic leader, discursive and ideology-centered definitions make it difficult to understand the central features of populism. While organized and truly empo- 
wered mass movements, such as European social democracy, form enduring collective actors who can systematically pursue a long-term reform strategy, populist leadership sustained by amorphous mass support is inherently unstable, fickle, and unpredictable. Populism is known for its twists and turns, fueled by the opportunistic efforts of personalist leaders to concentrate power and stay in office. The driving force behind populism is political, not ideological.

Prototypical populist movements are practically impossible to define in ideological terms. Argentine Peronism for decades spanned the entire arc from the fascist right to the radical left. And who could define the Bolivarianism of Hugo Chávez, who followed the advice of the reactionary Norberto Ceresole and the Marxist Heinz Dieterich? It does not seem useful to define populism through ideology; however thin it may be. Instead, it makes sense to conceptualize populism through the decisive role of personalistic and plebiscitary leadership. That top-down agency forms the axis around which

Populism turns out to be evident where an emerging mass movement loses strength and evaporates once its main leader dies, as happened after the death of Carlos Palenque in Bolivia and the assassinations of Jorge Eliécer Gaitán in Colombia and Pim Fortuyn in the Netherlands (Lucardie, 2008; Pelinka, 2013). Typical of populism is the way in which personalist leaders relate to their followers, seek to enhance their influence, and exercise their power. Consequently, populism is best defined as a distinctive political strategy.

\subsection{Confusion and Populism}

While the political-strategic definition clarifies the core of populism and usefully delimits its scope, the limits of this concept remain difficult to pin down; the distinction between ideocratic and pure opportunistic personalism is also not clear cut. Even more than other political phenomena, populism has fuzzy edges because in their quest for power, leaders flexibly adjust to contextual opportunities and constraints and change color with circumstances. While biology examines species that are genetically distinct, political phenomena lack clear boundaries. A cat is a cat and a dog are a dog, but in politics contextual complexity and human ingenuity soften or even erase boundaries; there may be partial and mixed types that the fixed conceptual categories do not fully capture. Given the opportunism of the leaders, populism in particular can be a "cat dog" (Makarychev \& Sazonov, 2019).

After all, political leaders can combine characteristics of different identities and strategies. For example, was Pancho Villa de México a bandit, revolutionary or populist? Was Hugo Chávez a socialist or a populist, that is, partly ideocratic or purely opportunist? Is Evo Morales of Bolivia a leader of a social movement or a populist?

In this binary categorization approach, cases are strictly within or completely outside the scope of a concept. This insistence on conceptual clarity promises analytical benefits. But it may be too blunt for the nuances and gray areas that characterize the political world in its tremendous complexity and fluidity. Espe- 
cially for a phenomenon that resembles both a chameleon and populism, a better procedure may be to rely on the fuzzy set approach propagated by Schneiker (2020). Fuzzy sets introduce conceptual gradations and qualitative thresholds that can capture the nuances and mixes of politics (Schneider \& Wagemann, 2012).

Therefore, fuzzy sets can represent political leaders who are primarily based on one strategy, but also based on another strategy as a complement. In their opportunistic pursuit of power and their disregard for ideological purity, it seems especially likely that populist politicians will apply such combinations of strategies. For example, Carlos Menem in Argentina sought and exercised power primarily as the personalist leader of a heterogeneous mass of citizens. But Menem also organized his Peronist Party (Partido Justicialista-PJ) and his affiliated unions; he used union support to win the PJ presidential candidacy for the 1989 race and relied on the party to help sustain his rule for the next decade. However, the Peronist Party did not constitute a firm and institutionalized base for political government. The PC is notoriously flexible in its procedures, programmatically ill-defined, deeply divided into factions, and therefore always "in need" of personalistic leadership. Lacking institutionalization, the PJ did not limit Menem's personalist leadership for many years; instead, the president quickly seized control of the party and submitted it to his will. Therefore, Menem's strategy was predominantly populist.

However, the Peronist Party gave Menem's rivals a base to guarantee their own political survival; Unlike wholly populist movements, such as the shifting electoral vehicles created and discarded by Alberto Fujimori and Hugo Chávez, Menem never succeeded in repressing or expelling all adversaries. Thus, when his personalist backing eroded in the late 1990s, Eduardo Duhalde was able to use his roots in traditionalist sectors of the PJ to block Menem's quest for another reelection and snatched the candidacy in the 1999 contest. Thus, Menem's dependence on the Peronist Party eventually blocked the perpetuation of his personalist leadership.

Therefore, Menem qualifies as predominantly populist, although not entirely. According to a fuzzy set approach, this case is more in than out of the category of populism. Charles Ragin's procedures would give Menem a fuzzy score of $66 \%$ on "populism." Alan García of Peru deserves the same score in his first term (1985-1990), during which he subjugated the American Popular Revolutionary Alliance (APRA) to his personalist leadership and obtained popularity ratings of up to $90 \%$, albeit temporarily. Álvaro Uribe occupies a similar position because his two-term presidency was based on massive disorganized support from his personalist leadership, but he had a background and continuous connections with Colombia's traditional parties.

Evo Morales of Bolivia also constitutes a mixed case because he applies various political strategies, but this combination is more outside than inside populism. Morales deserves a fuzzy score of $33 \%$ because his government relies heavily on the backing of powerful and contentious social movements, which have retained considerable autonomy and mobilization capacity. This massive base has 
continued to limit Morales' personal leadership and has blocked important government initiatives. Although the president has personalistic tendencies and populist aspirations, especially self-perpetuation in office, these goals have not achieved definitive advancement; Instead, the politicized and highly mobilized social movements of Bolivia have insisted on great responsibility and responsiveness, as evidenced by their furious and effective reaction to the December 2010 government "Gasolinazo" (De la Torre, 2017). In general, therefore, Morales and his Movement for Socialism do not qualify as populists (Weyland, 2017).

In contrast to these hybrid and partial cases, leaders like Fujimori, Chávez, Fernando Collor in Brazil and the Ecuadorian Rafael Correa, who enjoyed tremendous personal autonomy, founded their own flimsy electoral vehicles and were never limited by them, they count as a big scale. populists with a fuzzy score of $100 \%$. At the other extreme, leaders of well-organized parties, such as Luiz Inácio Lula da Silva in Brazil, Michelle Bachelet in Chile, and Tabaré Vázquez in Uruguay, rank $0 \%$ on the populism scale. While these politicians have gained considerable personal popularity, their organizational and institutional insertion has reliably limited personal ambitions, for example, excluding constitutional reforms to facilitate their reelection. Contemporary Latin American politics therefore encompasses the entire range of political strategies. A fuzzy set approach can locate different leaders and their political movements with a useful degree of clarity and precision.

The differentiated scoring of populism through Ragin's measurement approach can also help with European cases. For example, Silvio Berlusconi with his opportunistic personalism, weak electoral vehicle and great dependence on television qualifies as a complete populist with a score of $100 \%$; so, would the Dutch leader Pim Fortuyn (Lucardie, 2008). Andreas Papandreou, on the other hand, faced some limitations from his PASOK party, as did Pablo Iglesias from PODEMOS from Spain; Like the Argentine Menem, these leaders deserve, therefore, $66 \%$. Jörg Haider also qualifies as a populist leader because he decisively reoriented his party, softened his reactionary ideology, sought to maximize votes, and used alluring appeals and telegenic appearances for this purpose (Heinisch, 2003). Because of this transition from ideocratic dogmatism to opportunistic personalism, Haider deserves a $66 \%$ score on the populism scale. The reactionary Jean-Marie Le Pen, by contrast, who for decades put ideological radicalism above the popularity and appeal of the masses, is ranked $0 \%$, like most of the rightwing extremists in Europe (Mammone, 2009). Her daughter Marine hers, however, has taken a more flexible stance to win votes (Shields, 2013), as she ostentatiously highlighted in 2015 through the "costly sign" of expelling her own father from the movement. With her determined move toward opportunistic personalism, she now qualifies for a $66 \%$ populism score, as Haider did.

In short, by capturing the mixed strategies applied by various leaders, a fuzzy set approach is more realistic for measuring the complexity of this political context, especially the cat-dog of populism. Therefore, the strict binary classification 
advocated in (Weyland, 2001) is preferable.

\section{Conclusion}

This scientific contribution questions the economic, discursive and ideological definitions of populism and defends and develops a political-strategic conceptualization. Up to this point, this document has achieved a political-strategic conceptualization of populism. Populism is notoriously difficult to understand and has long been one of the most controversial concepts in the social sciences. However, upon further reflection, the very instability of this chameleon notion provides a crucial clue to its nature: populism revolves around the opportunism of personalist plebiscite leaders. The political-strategic approach highlights this astute leadership, which makes adequate use of available opportunities and often turns adversity into advantage. To ensure this maneuverability, populist leaders avoid committing themselves to a discourse, a worldview or an ideology, however focused it may be; in particular, they do not tie their political destiny to ideocratic visions. Instead, the substantive orientation of populist movements and governments remains ill-defined and subject to arbitrary changes, derived from calculations, elections, and even whims of the personalist leader.

\section{Conflicts of Interest}

The author declares no conflicts of interest regarding the publication of this paper.

\section{References}

Albertazzi, D., \& McDonnell, D. (2007). Twenty-First Century Populism: The Spectre of Western European Democracy. Palgrave Macmillan. https://doi.org/10.1057/9780230592100

Bavili, N. (2017). Policy Making in Populist Context. Open Journal of Political Science, 7, 432-439. https://doi.org/10.4236/ojps.2017.73034

Bravo Hidalgo, D., \& León González, J. L. (2018). Divulgación de la investigación científica en el Siglo XXI. Revista Universidad y Sociedad, 10, 88-97.

Bravo, D., González, F., \& González, J. (2018). Solar Cooling in Buildings. A State of the Art. Revista Ingeniería de Construcción, 33, 115-126. https://doi.org/10.4067/S0718-50732018000200115

Colomer, J. M. (1999). Las instituciones del federalismo. Revista española de ciencia política, No. 1, 41-54.

De la Torre, C. (2013). El tecnopopulismo de Rafael Correa: ¿Es compatible el carisma con la tecnocracia? Latin American Research Review, 48, 24-43. https://doi.org/10.1353/lar.2013.0007

De la Torre, C. (2017). Populism in Latin America. In C. R. Kaltwasser, P. Taggart, P. O. Espejo, \& P. Ostiguy (Eds.), The Oxford Handbook of Populism (pp. 195-213). Oxford University Press. https://doi.org/10.1093/oxfordhb/9780198803560.013.8

de Vreese, C. H., Esser, F., Aalberg, T., Reinemann, C., \& Stanyer, J. (2018). Populism as an Expression of Political Communication Content and Style: A New Perspective. The International Journal of Press/Politics, 23, 423-438. 
https://doi.org/10.1177\%2F1940161218790035

Dornbusch, R., \& Edwards, S. (1991). Introduction. In R. Dornbusch, \& S. Edwards (Eds.), The Macroeconomics of Populism in Latin America (pp. 1-4). University of Chicago Press.

Edwards, S. (2010). Left Behind: Latin America and the False Promise of Populism. University of Chicago Press. https://doi.org/10.7208/chicago/9780226184807.001.0001

Falkenbach, M., Bekker, M., \& Greer, S. L. (2020). Do Parties Make a Difference? A Review of Partisan Effects on Health and the Welfare State. European Journal of Public Health, 30, 673-682. https://doi.org/10.1093/eurpub/ckz133

Fiske, S. T. (2019). Political Cognition Helps Explain Social Class Divides: Two Dimensions of Candidate Impressions, Group Stereotypes, and Meritocracy Beliefs. Cognition, 188, 108-115. https://doi.org/10.1016/j.cognition.2018.11.007

Gibert, J. R. M., Gunther, R., \& Linz, J. J. (2007). Partidos políticos: Viejos conceptos y nuevos retos. Ed. Trotta.

Gibson, E. L., \& Falleti, T. G. (2007). La unidad a palos. Conflicto regional y los orígenes del federalismo argentino. Revista POSTData. Revista de Reflexión y Análisis Político, No. 12, 171-204.

Hawkins, K. A. (2009). Is Chávez Populist? Measuring Populist Discourse in Comparative Perspective. Comparative Political Studies, 42, 1040-1067. https://doi.org/10.1177\%2F0010414009331721

Hawkins, K. A. (2010). Venezuela's Chavismo and Populism in Comparative Perspective. Cambridge University Press. https://doi.org/10.1017/CBO9780511730245

Hawkins, K. A., \& da Silva, B. C. (2016). A Head-to-Head Comparison of Human-Based and Automated Text Analysis for Measuring Populism in 27 Countries. Manuscript, Department of Political Science, Brigham Youung University.

https://www.ceu.edu/sites/default/files/attachment/event/15587/hawkinssilvapolbergap ril16.pdf

Heinisch, R. (2003). Success in Opposition-Failure in Government: Explaining the Performance of Right-Wing Populist Parties in Public Office. West European Politics, 26, 91-130. https://doi.org/10.1080/01402380312331280608

Hirschl, T. A., \& Spisak, G. A. (2020). Is a New Structurally Dispossessed Class Developing in the United States? British Journal of Sociology, 71, 902-920.

https://doi.org/10.1111/1468-4446.12782

Laclau, E. (2005). On Populist Reason (276 p). Verso.

Laclau, E. (2009). Laclau en debate: Postmarxismo, populismo, multitud y acontecimiento (entrevistado por Ricardo Camargo). Revista de ciencia política (Santiago), 29, 815-828. https://doi.org/10.4067/S0718-090X2009000300007

Lucardie, P. (2008). The Netherlands: Populism versus Pillarization. In D. Albertazzi, \& D. McDonnell (Eds.), Twenty-First Century Populism (pp. 151-165). Palgrave Macmillan.

Madrid, R. L. (2008). The Rise of Ethnopopulism in Latin America. World Politics, 60, 475508. https://doi.org/10.1017/S0043887100009060

Madrid, R. L., Hunter, W., \& Weyland, K. (2010). The Policies and Performance of the Contestatory and Moderate Left. In K. Weyland, R. Madrid, \& W. Hunter (Eds.), Leftist Governments in Latin America: Successes and Shortcomings (pp. 140-180). Cambridge: Cambridge University Press.

https://doi.org/10.1017/CBO9780511778742.007 
Mair, P., \& Katz, J. (1997). Organización partidaria, democracia partidaria y la emergencia del partido Cartel. Traducción castellana de Party Sistem Change, Oxford, edit Univertsity, capítulo, 5.

Makarychev, A., \& Sazonov, V. (2019). Populisms, Popular Geopolitics and the Politics of belonging in Estonia. European Politics and Society, 20, 450-469. https://doi.org/10.1080/23745118.2019.1569341

Mammone, A. (2009). The Eternal Return? Faux Populism and Contemporarization of Neo-Fascism across Britain, France and Italy. Journal of Contemporary European studies, 17, 171-192. https://doi.org/10.1080/14782800903108635

Mazzuca, S. L. (2013). Lessons from Latin America: The Rise of Rentier Populism. Journal of Democracy, 24, 108-122. https://doi.org/10.1353/jod.2013.0034

McGarry, R. (2017). Demystifying the "Victimized State". Illness Crisis \& Loss, 25, 63-84. https://doi.org/10.1177\%2F1054137316675717

Mudde, C. (2007). Populist Radical Right Parties in Europe. Cambridge University Press. https://doi.org/10.1017/CBO9780511492037

Ofosu-Anim, D. O., \& Back, S.-H. (2021). Towards a Conceptual Framework for Political Leadership Theory and Practice: A Thematic Analysis of the Literature. Open Journal of Leadership, 10, 193-213. https://doi.org/10.4236/ojl.2021.103013

Orozco, S. A. P. (2016). Ciencia Política. Un manual, de Joseph M. Vallès y Salvador Martí i Puig. Revista Mexicana de Análisis Político y Administración Pública, 5, 233-236.

Pelinka, A. (2013). Right-Wing Populism: Concept and Typology. In: R. Wodak, M. KhosraviNik, \& B. Mral (Eds.), Right-Wing Populism in Europe: Politics and Discourse (pp. 3-22). Bloomsbury Academic.

Pierson, P. (2017). American Hybrid: Donald Trump and the Strange Merger of Populism and Plutocracy. British Journal of Sociology, 68, S105-S119.

https://doi.org/10.1111/1468-4446.12323

Roberts, K. M. (1995). Neoliberalism and the Transformation of Populism in Latin America: The Peruvian Case. World Politics, 48, 82-116. https://doi.org/10.1353/wp.1995.0004

Rooduijn, M. (2014). The Nucleus of Populism: In Search of the Lowest Common Denominator. Government and Opposition, 49, 573-599. https://doi.org/10.1017/gov.2013.30

Sachs, J. D. (1989). Social Conflict and Populist Policies in Latin America. National Bureau of Economic Research Cambridge. https://doi.org/10.3386/w2897

Schneider, C. Q., \& Wagemann, C. (2012). Set-Theoretic Methods for the Social Sciences: A Guide to Qualitative Comparative Analysis. Cambridge University Press. https://doi.org/10.1017/CBO9781139004244

Schneiker, A. (2020). Populist Leadership: The Superhero Donald Trump as Savior in Times of Crisis. Political Studies, 68, 857-874. https://doi.org/10.1177\%2F0032321720916604

Shields, J. (2013). Marine Le Pen and the 'New' FN: A Change of Style or of Substance? Parliamentary Affairs, 66, 179-196. https://doi.org/10.1093/pa/gss076

Svampa, M. (2013). El dilema del populismo plebeyo. Revista Ñ.

Taggart, P. A., \& Parkin, F. (2000). Populism. Open University Press.

Weyland, K. (1996). Neopopulism and Neoliberalism in Latin America: Unexpected Affinities. Studies in Comparative International Development, 31, 3-31.

https://doi.org/10.1007/BF02738987 
Weyland, K. (2001). Clarifying a Contested Concept: Populism in the Study of Latin American Politics. Comparative Politics, 34, 1-22. https://doi.org/10.2307/422412

Weyland, K. (2017). A Political-Strategic Approach. In C. R. Kaltwasser, P. Taggart, P. O. Espejo, \& P. Ostiguy (Eds.), The Oxford Handbook of Populism (pp. 48-73). Oxford University Press.

Zúquete, J. P. (2007). Missionary Politics in Contemporary Europe. Syracuse University Press. 